\title{
超音波を利用した関節軟骨の非接触評価*
}

\author{
森浩二*1, 中川泰 彰*2, 黒木 裕 士*3 \\ 中 嶋啓介*1, 池内健*4, 峯孝友*5 \\ 中 村孝志 ${ }^{* 2}$, 河合伸也*5, 斉藤俊*1
}

\section{Non-contact Evaluation for Articular Cartilage Using Ultrasound}

\author{
Koji MORI*6, Yasuaki NAKAGAWA, Hiroshi KUROKI, \\ Keisuke NAKASHIMA, Ken IKEUCHI, Takatomo MINE, \\ Takashi NAKAMURA, Shinya KAWAI and Takashi SAITO \\ ${ }^{* 6}$ Applied Medical Engineering Sciences, Graduate School of Medicine, Yamaguchi University, \\ 2-16-1 Tokiwadai, Ube-shi, Yamaguchi, 755-8611 Japan
}

\begin{abstract}
In orthopedic field, various new treatments of articular cartilage defect, for example autogenous osteochondral grafts, have been developed. With the spread of these treatments, orthopedists began to focus on the mechanical properties of recovered articular cartilage. The quantiative evaluation of articular cartilage before and after these treatments gives orthopedists the important information to improve these treatments and develop new treatments. We have been investigating the noncontact ultrasonic evaluation for articular cartilage under arthroscopy. In this paper, it was hypothesized that the ultrasonic evaluation depended on the collagen fiber in cartilage. The enzymatically degradation of collagen fiber in cartilage surface was performed. The effect of the degradation on sound velocity, attenuation coefficient and signal intensity, which is the index of cartilage stiffness calculated from the proposed method, was measured. The numerical analysis was performed to clear the relation between the cartilage character and ultrasonic parameters. Experimental and numerical results suggest that the present method can be expanded the sensitive evaluation for cartilage disease in clinical field.
\end{abstract}

Key Words : Ultrasound, Cartilage, Surface, Wavelet Transform, Non-contact Evaluation

\section{はじめに}

関節軟骨は, 関節部分の骨端部に位置し, 骨と骨が 滑らかに動くことを助け，その運動に伴う大きな荷重 を負担する組織である．この関節軟骨は自己修復能力 に乏しいと言われ, 変形性関節症などで一度, 関節軟 骨が変性すると治療方法は無いと考えられてきた。し かしながら近年の治療技術の向上により様々な関節軟 骨の治療法が試みられ, その有効性が確認されている.

整形外科領域においては関節軟骨の状態を把握する ために，低侵襲な関節鏡を利用して関節腔内を直接観 察する方法が用いられる.しかし狭い関節腔内では, 関節軟骨の状態を定量的に診断するのは困難であり, これまでは画像による表面亀裂の有無等の確認や, 細 い金属棒を関節軟骨に直接押しあて，その手に伝わる 反力から軟骨のヤング率を推測する方法が一般的で

\footnotetext{
* 原稿受付 2004 年 3 月 10 日.

*1 正員, 山口大学大学院医学研究科( - 755-8611 宇部市常盤 台 2-16-1).

*2 京都大学大学院医学研究科 (-606-8501 京都市左京区吉田 近衛町).

*3 京都大学医学部保健学科.

*4 京都大学再生医科学研究所.

*5 山口大学大学院医学研究科.

E-mail : kjmori@yamaguchi-u.ac.jp
}

あった。しかしこれらの方法では関節軟骨の定量的な 状態把握は困難であり，近年の治療技術の向上に見合 う情報を収集することは出来ない。

関節軟骨の定量的評価としては Aggregate modulus $^{(1)}$ という指標が用いられている。これ は関節軟骨の固体層におけるヤング率に相当する指 標であり, インデンテーション試験と呼ばれる押し込 み試験 ${ }^{(2)(3)}$ により測定可能である。この Aggregate

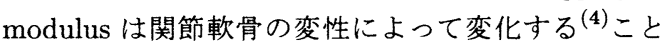
が報告されており，この指標を用いれば関節軟骨の定 量評価が可能になる.

このような背景から関節軟骨の変性および修復過 程において, 関節軟骨の状態を表す重要な指標となる Aggregate modulus や厚さなどを，関節鏡視下におい て定量的に把握したいというニーズが高まっている. Töyräs $ら^{(5)}$ は関節腔内で押し込み試験が出来る装置 を開発し，押し込み試験による関節軟骨の定量評価法 を提案している. またUchio ら ${ }^{(6)}$ は, 超音波触覚セン サーが測定対象物のヤング率によりセンサーの共振周 波数が変化することを利用して, 再生関節軟骨の評価 
を行っている。これらの測定法は関節軟骨の硬さを測 定することは出来るが, 臨床医学的に重要な指標の 1 つである軟骨厚さを計測することは出来ない。

そこで我々は, 超音波を関節軟骨に照射し，その関 節軟骨表面からの反射波をウェーブレット変換すると, その最大強度 (以下, Signal intensity) が関節軟骨の Aggregate modulus と相関があることを利用して関節 軟骨の定量評価を提案してきた ${ }^{(7)(8)}$.ここの方法は超音 波を送受信する探触子と関節軟骨表面が接触せずに測 定を行うことが出来るため, 関節軟骨一侵襲を最小限 に抑えることが出来る. また超音波は異なる音響イン ピーダンスの境界面で反射するので，関節軟骨表面と 軟骨下骨 (関節軟骨の下部に位置する組織) から反射 エコーが得られる。この両者の反射波の時間間隔が関 節軟骨の厚さに相関しており，関節軟骨の厚さも測定 できる ${ }^{(8)}$.

しかしながら本方法による評価については関節軟骨 のどの領域, どの特性の情報を反映しているのか不明 であった。それらを明確にすることは本方法を臨床に 応用するに際して重要な課題である。一般に関節軟骨 の超音波による測定に関しては, 関節軟骨中のコラー ゲン線維が大きな影響をおよぼしているといると言わ れている、そこで本研究では竹中・服部ら ${ }^{(9)(11)}$ の方 法をもとに関節軟骨変性を関節軟骨中のコラーゲン線 維を酵素処理・分解することによって再現した。 その 際の Signal intensity の変化から本方法の評価原理に ついて考察を行った。また関節軟骨の音速・減衰係数 といった音響学的パラメータの変化も調べ,これらの 評価法との比較により本方法の特徵について調べた.

\section{1. 実 験 方 法}

1.1 関節軟骨試料試料にはブタ膝関節の大腿 骨膝蓋面より採取した関節軟骨を用いた。ブタ膝関節 は実験時まで- $28{ }^{\circ} \mathrm{C} て ゙$ 保存され，実験開始前日から室 温で解凍された。解凍されたブタ膝関節の関節包に損 傷がないことを確認した後, 大腿骨膝蓋面から関節軟 骨を直径 $8.0 \mathrm{~mm}$ の円柱状に軟骨下骨・海面骨ともに切 り出し試験片とした (Plug specimen). 関節軟骨のコ ラーゲン線維をコラゲナーゼ酵素によって分解するこ とにより, 関節軟骨を変性させて関節疾患を模擬でき $ろ^{(10)}$. コラゲナーゼを $30 \mathrm{unit} / \mathrm{ml}$ の濃度で Phosphate Buffuered Saline(PBS) に溶解させ, 酵素液を作製し た。この酵素液を用いて関節軟骨を $0,0.5 ， 1 ， 2 ４$

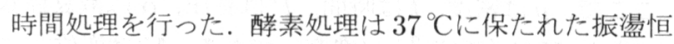
温水槽で行われた。この酵素液で処理を行ったところ, 表面からコラーダン線維の分解が行われ ${ }^{(9)(11)}, 4$ 時間
処理した試料では，厚さ約 $1.0 \mathrm{~mm}$ の関節軟骨が表面 から約 $500 \mu \mathrm{m}$ の領域においてコラーゲン線維が分解 されていた．本研究での処理時間は，関節軟骨変性の 初期の状況を再現するために設定したものである。こ の酵素処理を行ったPlug specimen の Signal intensity を計測し、コラーゲナーゼ処理による Signal intensity への変化を調べた.

さらに音速・減衰係数を測定するために関節軟骨部 分のみを切り出し, 関節軟骨の表層部分および深層部 分をそれぞれ数 $10 \mu \mathrm{m}$ づつミクロトームにて切除し， 表層面および深層面を平行になるようにしてディスク 状の試験片 (Disk specimen) を作製した (図 1 参照).

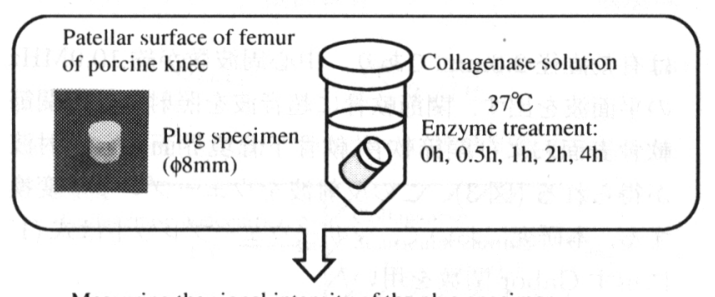

Measuring the signal intensity of the plug specimen

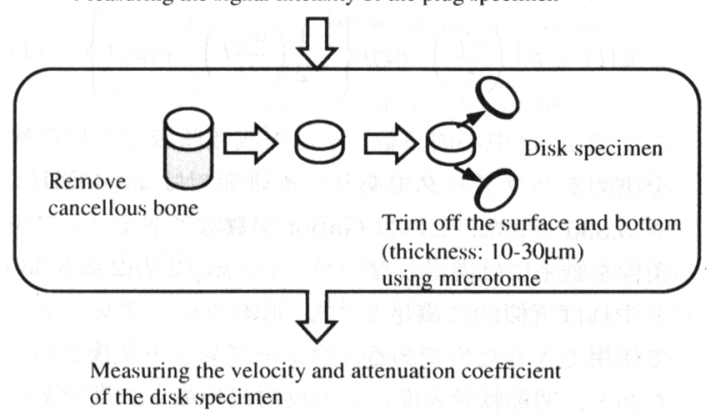

Fig. 1 Specimen preparation

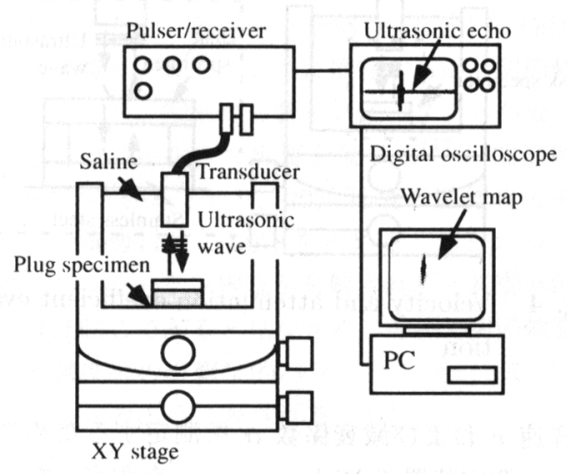

Fig. 2 Signal intensity evaluation

1.2 超音波試験 関節軟骨の Signal intensity 測定するため図 2 の測定装置を用いた，超音波探触子 


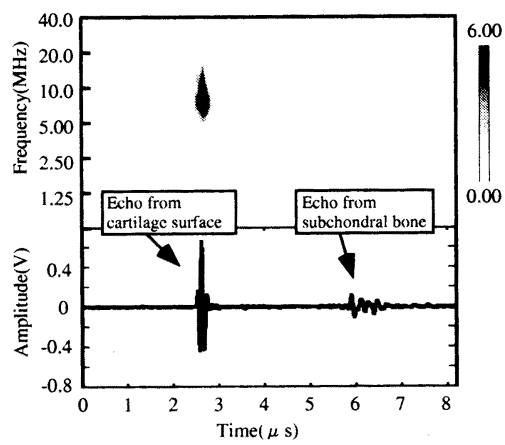

Fig. 3 Typical ultrasonic echo and wavelet map

は有効直径 $2.0 \mathrm{~mm}$ であり，中心周波数が約 $10.0 \mathrm{MHz}$ の平面波を出す．関節軟骨に超音波を照射すると関節 軟骨表面および関節軟骨-軟骨下骨境界面から反射波 が得られる (図 3 ). この反射波をウェーブレット変換 する. 本研究において, マザーウェーブレットは式 (1) に示す Gabor 関数を用いた。

$$
\psi(t)=\pi^{\frac{1}{4}}\left(\frac{\omega_{p}}{\gamma}\right)^{\frac{1}{2}} \exp \left\{-\frac{1}{2}\left(\frac{\omega_{p}}{\gamma} t\right)^{\frac{1}{2}}+i \omega_{p} t\right\}
$$

ここで $\omega_{p}$ は中心周波数, $\gamma$ は周波数領域での局在幅 を決めるパラメータであり, 本研究では $\omega=40 \mathrm{MHz}$, $\gamma=5.336$ とした。 これは Gabor 関数はアドミッシブル 条件を厳密には満足しないが, $\gamma=\pi \sqrt{2 / \ln 2} \approx 5.336$ とすれば近似的に満足し(12), 基本ウェーブレットし て使用できるためである．ウェーブレット変換を行っ たあと，関節軟骨表面からの反射波の最大強度である Signal intensity を求めた.

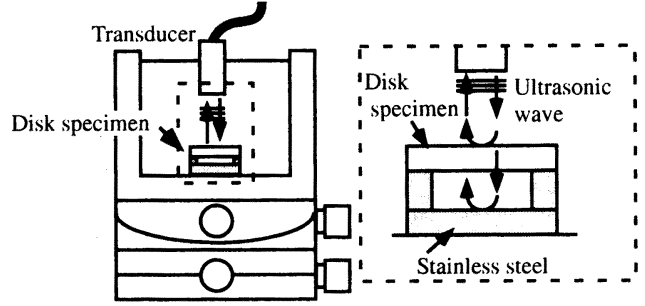

Fig. 4 Velocity and attenuation coefficient evaluation

音速 $v$ および減衰係数 $\alpha$ を測定するために図 4 に示す測定装置で Disk specimen を測定した。 Disk specimen に超音波を照射すると図 5 のような反射波 が得られる. Echo A，Bおよび C はそれぞれ関節軟 骨表層面，深層面，およびステンレス板からの反射波 である. Disk specimen の厚さ $T$ が既知の場合, 音速

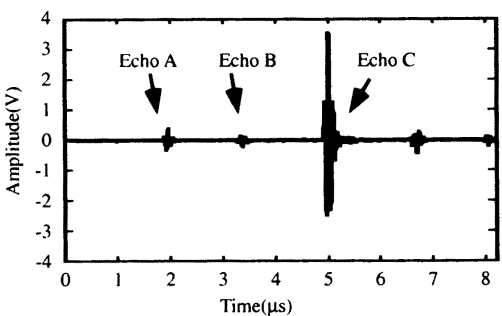

Fig. 5 Typical ultrasonic wave for measurement of velocity and attenuation coefficient

$v$ は Echo A と B の時間間隔 $d t$ から,

$$
v=\frac{2 T}{d t}
$$

求められる.また減衰係数 $\alpha$ は Disk specimen が存在 する場合の $\mathrm{Echo} \mathrm{C}($ 波形を $C s(t)$, そのフーリエ変換 、を $\overline{C s}(f))$ とDisk specimen が存在しない場合の Echo $\mathrm{C}($ 波形を $C r(t)$, そのフーリエ変換を $\overline{C r}(f))$ から，

$$
\alpha=-\frac{1}{2 T} \ln \frac{\overline{C r}(f)}{\overline{C s}(f)}
$$

で求められる ${ }^{(13)}$. 関節軟骨をはじめとする生体組織 の減衰係数は図 6 のように周波数にほぼ線形に比例す $3^{(14)}$. 本研究では反射波の中心周波数における減衰 係数を测定した.

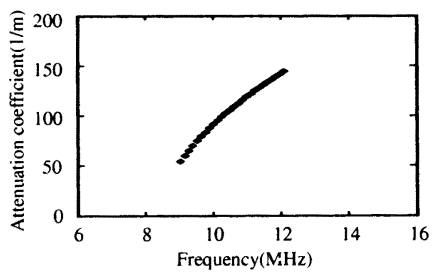

Fig. 6 Frequency dependence of attenuation coefficient of articular cartilage

1.3 数值解析と解析モデル 酵素処理による関 節軟骨内の物性変化が超音波評価法におよぼす影響を 調べるために数值解析を行った．超音波の伝播は波動 方程式によってあらわされる.

$$
\begin{aligned}
& \frac{\partial V}{\partial t}=-\frac{1}{\rho} \frac{\partial P}{\partial x}-K \alpha V \\
& \frac{\partial P}{\partial t}=-K \frac{\partial V}{\partial x}-K \alpha P
\end{aligned}
$$

ここで, $\rho$ は密度, $t$ は時間, $P$ は音圧, $\alpha$ は減衰係数 であり $K$ は $(\text { 音速 })^{2} \times$ (密度) である. $V$ は変位 $u に$ 対して $V=\partial u / \partial t$ の関係が成り立つ.これらの波動 方程式を低次の差分法で解く場合, 解析対象の大きさ 
が波長よりも非常に大きくなると正確な解を得ること は難しくなる。そこで Wojcik ら ${ }^{(15)}$ は式 (4)の $\partial P / \partial x$ や $\partial V / \partial x$ の項を FFT を利用した擬スペクトル法を利 用することにより精度よく計算し，それによって大規 模なモデルでも正確に超音波の伝播を解析できること を示した.また FFTを利用した擬スペクトル法は周期 対称条件下で使用するが，解析対象の境界にPerfectly Matched Layer(PML) ${ }^{(16)}$ を配置することにより音波 が境界部分で反射・透過するのを防ぎ，周期対称条件 ではない条件下で解析できるように工夫した，本研究 では Wojcikらの方法を利用して, 関節軟骨内部の物 性を変化させて, それが関節軟骨を伝播する超音波に およぼす影響を解析した。

実際の関節軟骨計測は生理食塩水中で行われる。ま た関節近傍は関節軟骨・軟骨下骨・海綿骨からなる層 状構造をしている. そこで図 7 のような解析モデルで 解析を行った。解析モデルの格子間隔は $0.015 \mathrm{~mm}$ で ある (解析領域の大きさは 512 グリッド $\times 256$ グリッ

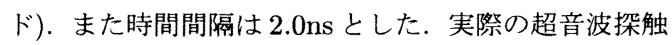
子による測定は, 音圧を探触子が電圧に変換して, そ の電圧をオシロスコープに表示する.そしてその波形 を元にして関節軟骨の評価を行う。そこで図 7 中に実 際の計測に使用している超音波探触子の大きさと同じ 幅 $2.0 \mathrm{~mm}$ の検查領域を設定し，この領域での音圧の 総和を探触子で測定された超音波反射波とみなし評価 を行った。入射波には実際の超音波探触子の波形 (中 心周波数約 $10.0 \mathrm{MHz}$ ) を用いた。材料物性值は文献值 (17)を参考にした。

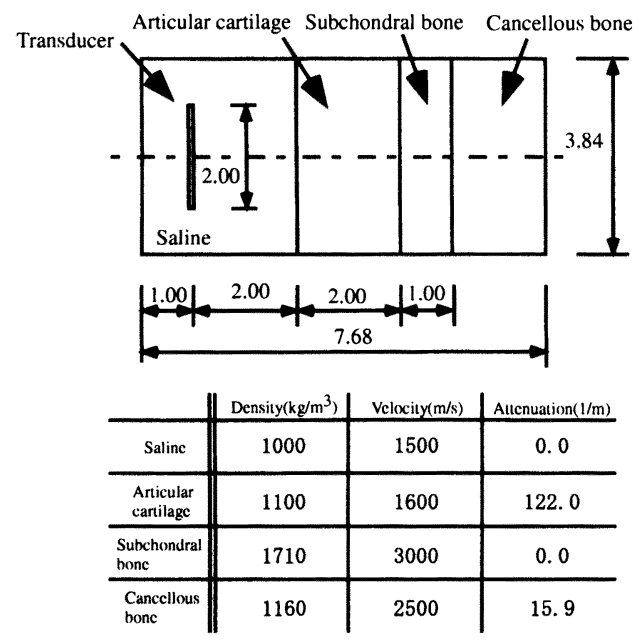

Fig. 7 Analysis model and material parameters
1.4 数值解析モデルにおける物性分布 実験で はコラーゲン線維を分解するコラゲナーゼ酵素溶液中 に関節軟骨試料を浸し，関節軟骨中のコラーゲン線維 を分解する. ある時刻 $\mathrm{t}(\mathrm{h})$ における関節軟骨中の任 意の位置 $x(\mathrm{~m})$ におけるコラゲナーゼ濃度 $G_{e n z}(x, t)$ は拡散方程式

$$
\frac{\partial^{2}}{\partial x^{2}} G_{e n z}(x, t)=\frac{1}{D} \frac{\partial}{\partial t} G_{e n z}(x, t)
$$

で表される. $D\left(\mathrm{~m}^{2} / \mathrm{h}\right)$ は拡散係数である.ここで図 8 のように関節軟骨部分を半無限物体とみなし, 関節軟 骨内部の初期のコラゲナーゼ濃度を 0 , 酵素溶液のそ れを 1.0 とすると, 関節軟骨中のコラゲナーゼ濃度は,

$$
G_{e n z}(x, t)=-\operatorname{err} \frac{x}{2 \sqrt{D t}}+1
$$

となる. $\operatorname{err}(x / 2 D t)$ はガウスの誤差関数である.

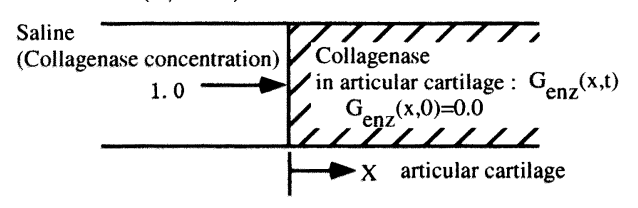

Fig. 8 Collagenase distribution model

関節軟骨内のコラーゲン線維はコラゲナーゼ酵素に よって即時に分解されるならば，関節軟骨中のコラー ゲン線維量を 1.0 とすると $1-G_{\text {enz }}(x, t)$ となる. し かし実際は分解されるまである程度の時間が必要であ るので，それを考虑して関節軟骨中のコラーダン線維 分布 $F_{c o l}(x, t)$ を

$$
F_{c o l}(x, t)=1-0.2 t \times G_{e n z}(x, t)
$$

とした.ところで超音波の伝播は (音速) $\times$ (密度)か らなる音響インピーダンスに依存するが，関節軟骨中 ではコラーゲン線維の音響インピーダンスが最も大き く，その分布に大きな影響を受ける ${ }^{(17)}$. 関節軟骨は $70 \sim 80 \%$ が水分であり， $20 \%$ 程度の固体成分中，コ ラーゲン線維はその $60 \%$ を占める。 したがって関節 軟骨中のコラーゲン線維が分解されると音響学的には 水とほぼ同じであると見なせる.そこで関節軟骨中の 音速や密度等の音響学的パラメータ $A p$ は式 (7) を用 いて, 次式のように表されると仮定した。

$A p(x, t)=A p_{\text {saline }}+\left(A p_{\text {cartilage }}-A p_{\text {saline }}\right) \times F_{\text {col }}(x, t)$

式中の $A p_{\text {cartilage }}$ は図 7 に示す関節軟骨の音速等の音 響学的パラメータであり, Ap saline は生理食塩水のそ れを表す.一例として図 9 に $t$ を変更した場合の音速 
分布を示す. 式 (6) の拡散係数 $D$ は, 前節の実験から $4 \mathrm{~h}$ 処理後に表面から約 $500 \mu \mathrm{m}$ までコラーゲン線維が 分解されていることから $\mathrm{D}=1.0 \times 10^{-8}\left(\mathrm{~m}^{2} / \mathrm{h}\right)$ とした.

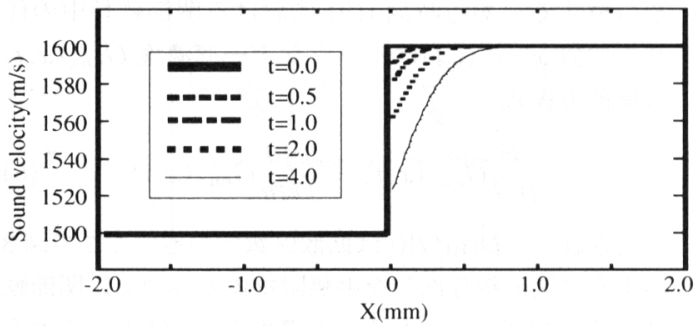

Fig. 9 Sound velocity in aricular cartilage

1.5 臨床での超音波評価京都大学付属病院にお いて, 2001 年 10 月から 2002 年 3 月に患者の同意を得 て人工膝関節置換手術時に関節軟骨の Signal intensity 評価を行った．合計 9 膝の測定を行い， 1 䊫あたり 19 から 36 点のデータを測定した。測定部位は膝蓋骨・大 腿骨・脛骨の関節面であり，これらの部位の関節軟骨 の損傷度と Signal intensity の関係について調べた。関 節軟骨の損傷度は，臨床で一般的に用いられる肉眼的 な損傷度評価法である International Cartilage Repair Society(ICRS) の軟骨変性分類 ${ }^{(18)}$ により評価した，以 下に定義を示す.

Grade 0:正常な軟骨

Grade 1:表層のみ損傷または変化

Grade 2:軟骨層の $1 / 2$ までの損傷または変化

Grade 3:軟骨層の $1 / 2$ 以上の損傷または変化

Grade 4:軟骨が欠損し軟骨下骨が露出

超音波による測定を行うためには超音波探触子と関 節軟骨の間に液体が介在する必要がある。そこで図 10 のような装置を用いて測定を行った。本装置を用いる ことによって強制的に生理食塩水を探触子と関節軟骨 の間に供給することが出来る.
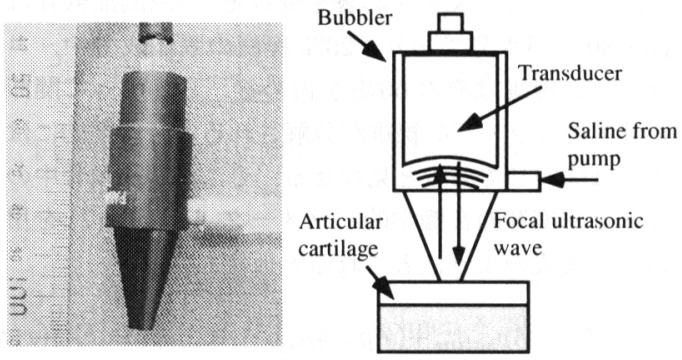

Fig. 10 Ultrasonic probe for clinical use

\section{2. 結果}

2.1 酵素処理実験図 11～13 は超音波評価に おける各種測定值の酵素処理時間による変化を示し たものである. Signal intensityは処理時間に比例 して減少しており，0h と $4 \mathrm{~h}$ を比較すると, $0 \mathrm{~h}$ で $4.08( \pm 0.52)$ から $4 \mathrm{~h}$ で $1.12( \pm 0.52)$ と $72.4 \%$ の減 少 $(\mathrm{p}<0.05)$ であった。一方, 音速は処理時間で比 較すると $0 \mathrm{~h}$ で $1625.9( \pm 21.0)(\mathrm{m} / \mathrm{s})$ であるのに対し て, $4 \mathrm{~h}$ では $1639.8( \pm 32.4)(\mathrm{m} / \mathrm{s})$ であり, $0.86 \%$ とわ ずかながら増加 $(\mathrm{p}<0.05)$ した。また減衰係数は $0 \mathrm{~h}$ で $107.8( \pm 56.7)(1 / \mathrm{m})$ が $4 \mathrm{~h}$ で $89.8( \pm 54.6)(1 / \mathrm{m})$ と $16.2 \%$ の減少 (有意差なし) であった。音速および減 衰係数は Signal intensity に比べると，酵素処理によ る測定值の変化は小さかった。このことから Signal intensity は関節軟骨表面の性状変化 (コラーゲン線維 の酵素処理による分解) に対して非常に敏感な指標で あるといえる。

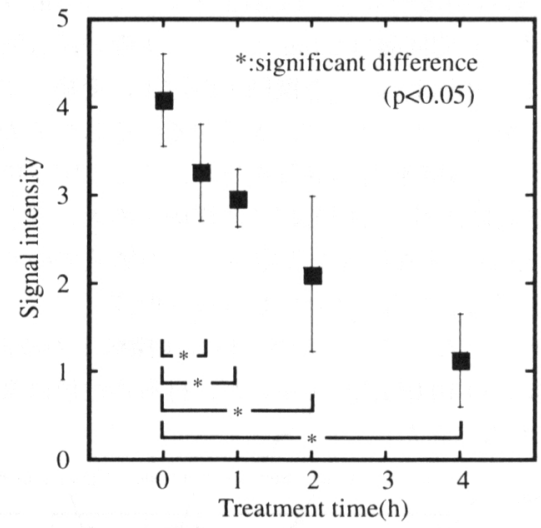

Fig. 11 Relation between signal intensity and treatment time

$2 \cdot 2$ 解析結果 図 14 に $F_{c o l}(x, 0)$ の場合 (関節 軟骨内での音響学的パラメーターは一定) における超 音波伝播の様子を示寸。探触子から発振された超音波 は右方向に伝播していく $(t=0.6 \mu s)$. そして関節軟 骨表面部分で反射し，その反射波は探触子の方向に向 かっていく $(t=1.2 \mu s)$. 更に時間が経過すると軟骨 下骨部分でも反射し, その反射波は探触子のほうに向 かっていく $(t=1.8 \mu s)$. この図から Signal intensity を求める関節軟骨表面からの反射波は, 生理食塩水関節軟骨の境界面で発生しており, 関節軟骨表面部分 の影響を強く受けることが予想される.

図 15 に Signal intensity が式 (7)の $t$ によりどのよ 


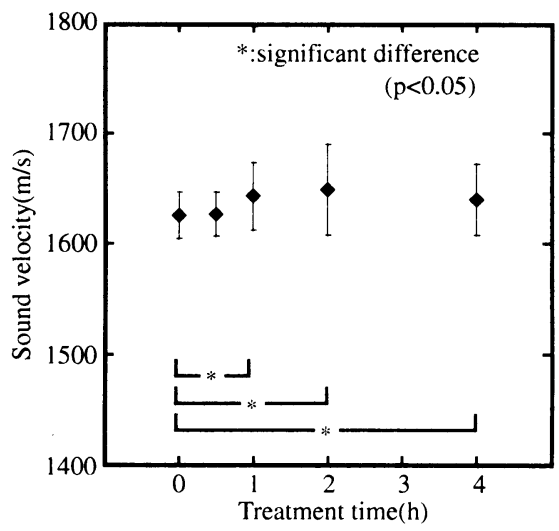

Fig. 12 Relation between sound velocity and treatment time

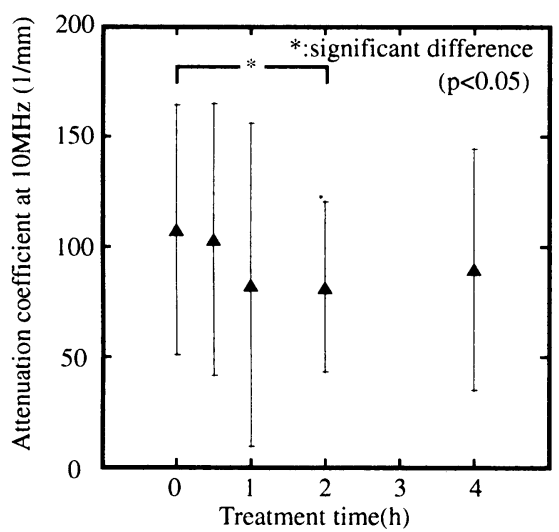

Fig. 13 Relation between attenuation coefficient and treatment time

うに変化するかを示す. 図 11 と同様に $t$ の増加にし たがって線形に減少していることがわかる. 数值解析 で用いた音響パラメータ分布は図 9 に示すように処理 時間の経過と共に関節軟骨表面近傍の音響パラメータ が変化している.

そこで関節軟骨表面から 1 波長の領域 $(1600(\mathrm{~m} / \mathrm{s}) / 10.0 \mathrm{MHz}=160 \mu \mathrm{m})$ におけるコラー ゲン線維分布関数 $F_{\text {col }}$ の平均值に注目した。 各処理 時間における Signal intensity, 音速および減衰係数 の変化を図 16 に示す. 音速等は $F_{c o l}(x, 0)$ の場合を 基準として正規化している．音速や減衰係数の変化 に比べ, Signal intensity は大きく変化した。 また音 速は $0.36 \%$ の減少であり, 減衰係数は音速と比較す

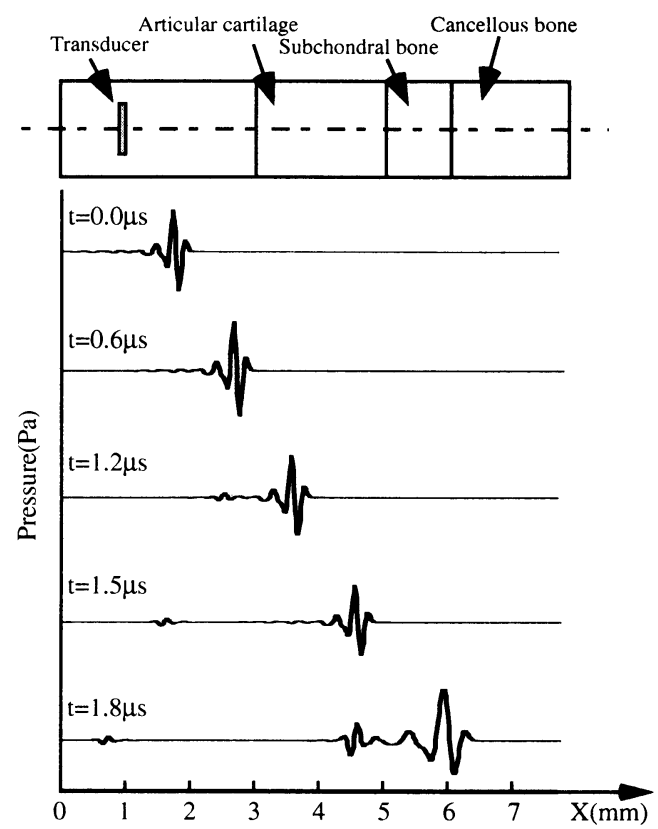

Fig. 14 Ultrasonic wave propagation

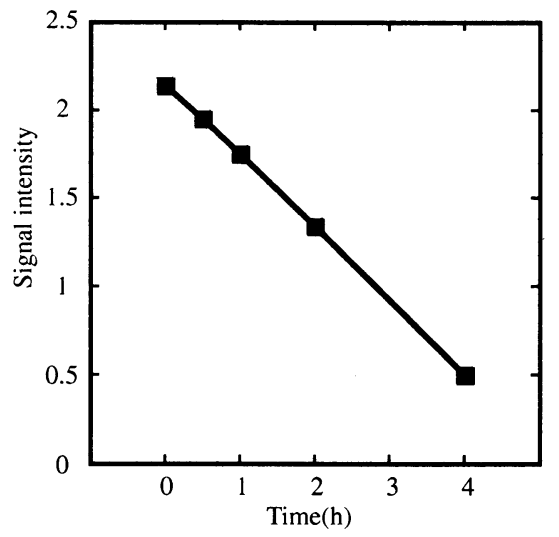

Fig. 15 Signal intensity change from numerical analysis

ると変化率は大きく, $5.1 \%$ の減少であった．これら は実験と同様の傾向である.

2.3 臨床での測定結果図 17 に臨床での測定結 果を示す. Grade 4 は関節軟骨が消失しているために 結果から省略している. 図 17 から損傷度の進行につれ て Signal intensity が減少している. 特に変性の初期 段階である Grade1 は正常軟骨 (Grade 0) に対して大 きく減少している.しかしながら Grade1 から Grade2 


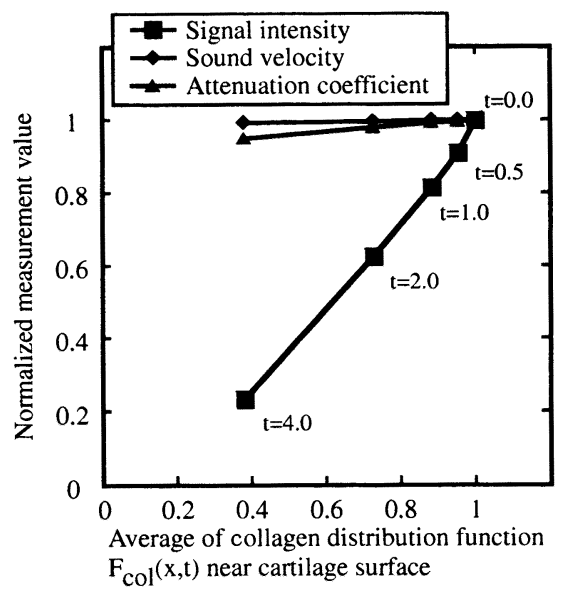

Fig. 16 Effect of collagen function $F_{c o l}(x, t)$ on acoustic parameters

への Signal intensity 変化は小さくなり, Grade 2 と Grade 3 ではほぼ同じ Signal intenstiy になっている.

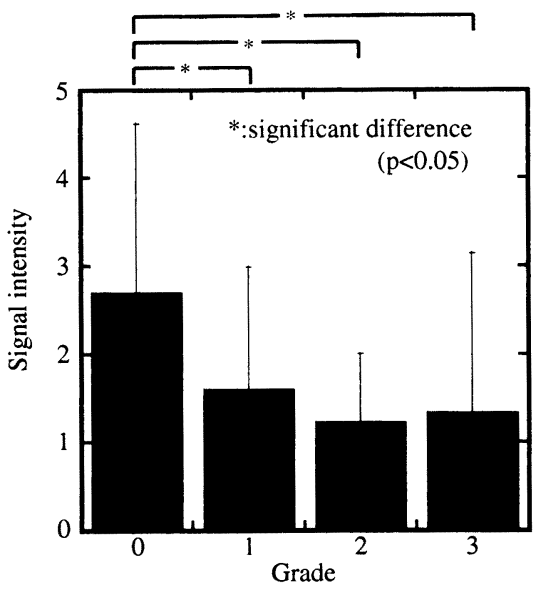

Fig. 17 Relation between signal intensity and cartilage damage

\section{3. 考察}

本研究では, 超音波の Signal intensity が反映して いる物性および領域を特定することを目的として実験・ 解析を行った. 数值計算から Signal intensity は関節 軟骨表面付近の音響インピーダンスの変化に敏感であ ることがわかった。また関節軟骨中のコラーゲン線維 の影響を調べた結果, 酵素処理開始から時間経過と共
に減少した．酵素処理によって関節軟骨表面付近から

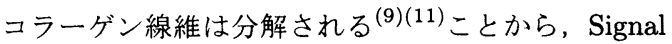
intensityは関節軟骨表面付近のコラーゲン線維量を反 映していることが推定できる.

関節軟骨はコラーゲン線維が引張応力を負担し, プ ロテオグリカンが，その浸透圧を利用して関節軟骨 に作用する圧縮応力を負担している. またコラーゲ ン線維はネットワークを形成しており，プロテオグリ カンをそのネットワークの網目の中に拘束している. したがってコラーゲン線維が消失するとプロテオグリ カンも関節軟骨中に留まることが出来ず, 関節軟骨の 力学的機能は大幅に減少する。これらを考慮すると Aggregate modulus はコラーゲン線維の消失に伴い, 大幅に減少する ${ }^{(11)(19)}$ といえる.

以上のことを考慮に入れると, 我々は Signal intensity は関節軟骨のヤング率に相当する Aggregate modulus という力学特性値を反映していると報告して きた ${ }^{(8)(11)}$ が，実際には Signal intensity と Aggregate modulus は直接的に相関があるのではなく, 表面付 近のコラーゲン線維量を介して間接的に Aggregate modulus を推定していたと言う方がより正確である.

臨床での測定結果において, 正常軟骨である Grade0 と軽度の損傷である Grade1 の間の変化が最も大きかっ た. 関節疾患における関節軟骨の変性は, ICRS の分 類法 ${ }^{(18)}$ が示すように表面部分から起こる. 本方法は 関節軟骨の力学特性を直接的に測定していない反面, 関節軟骨の表面部分の性状を反映することは実験・解 析から明らかである. 臨床での測定結果は, 本方法は 関節疾患の初期状態の診断には適していることを示唆 している.

超音波を利用した関節軟骨の特性評価には音速や减 衰係数を用いて様々な観点から研究が行われている. Myers ら ${ }^{(20)}$, Töyräs ${ }^{(21)}$ は, 関節軟骨の厚さをあ らかじめ測定し，それと関節軟骨表面および軟骨下骨 からの反射波の伝播時間から音速を計測した．正常軟 骨での音速 $1650 \mathrm{~m} / \mathrm{s}$ 程度が, 変性した関節軟骨では $1550 \mathrm{~m} / \mathrm{s}$ 程度に有意に低下することを明らかにした。

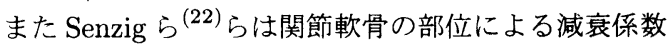
の変化に注目し，10-40MHz での減衰係数の平均值が 300-720 $(1 / \mathrm{m})$ であり, 膝蓋大腿関節において膝関節 面に近づくほど減衰係数が減少することを報告してい る. Agemura ら ${ }^{(17)}$ は $100 \mathrm{MHz}$ の超音波顕微鏡を用い て関節軟骨を測定し, 関節軟骨の減衰係数は関節軟骨 内でのタンパク質の有無やコラーゲン線維の結合の状 態により恋動すると報告している.

しかしながら音速や減衰係数を用いての関節軟骨評 
価は，事前に関節軟骨厚さが既知である必要があつた り, 複数の探触子を組み合わせてた測定装置が必要で ある。また軟骨変性に対して，これらの測定值の変化 率は $10 \%$ 以下 ${ }^{(20)(21)}$ と小さい. 一方, Signal intensity の測定に際しては, 事前に関節軟骨の厚さ等の情報取 得は必要なく 1 探触子によって測定可能である. また図 11 に示すように関節軟骨変性に対する Signal intensity の変化率は大きい.

本研究で提案する方法は 1 探触子による測定法であ り，装置の小型化が容易である．PCに取り込まれた 波形はリアルタイムにウェーブレット変換され, PCの 画面上に測定波形およびウェーブレットマップを表示 し，医師に関節軟骨の情報を提示する. ウェーブレッ トマップは図 3 に示すように超音波波形を直感的・視覚 的に認識しやすく ${ }^{(8)}$, 臨床での応用に適しているとい える. 現在は, 人工膝関節置換手術時での測定を中心 に行っているがプローブの位置調整を含め, 数秒で 1 点あたりの測定が終了する.これらの特徵から Signal intensity の測定は, 関節軟骨表面から性状変化が進行 する関節疾患に関しては, その進行程度, 特に初期状 態における定量的診断法になりうると考えられる. 一 方で, 反射波は関節軟骨の形状や表面粗さによって振

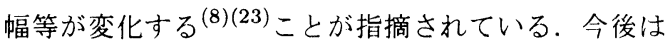
Signal intensity と各種臨床医学的指標との相関を調 べ, 診断方法・装置としての精度向上を目指す予定で ある。

\section{4. 結}

関節鏡視下で関節軟骨の定量評価を行う方法として, 超音波を関節軟骨に照射し，そこから得られる反射波 をウェーブレット変換する方法を提案した. 本方法で 得られる Signal intensity が関節軟骨のどのような物 性を反映しているのかを明確化するために, 酵素処理 により関節疾患を模擬した In vitro 実験および数值解 析を行った。 また臨床でヒト膝関節の関節軟骨を測定 し, 実験・解析で得られた結果を検証した。 その結果, Signal intensity は関節軟骨表面近傍のコラーゲン線 維量の影響を強く受けることがわかった。これは関節 疾患の初期状態を精度よく測定できることを示してお り，臨床での測定結果でもそれが裏付けられた。

\section{5. 謝辞}

本研究は NEDO 産業技術研究助成事業の助成を受 けたものであることを付記し，謝意を表する．

\section{文献}

(1) Mow,C.V., Kuel,C.S. et al., J. Biom. Eng., 102, 1980, 73-84.

(2) Mak,F.A., Mow,C.V. et al., J. Biomech., 20(7), 1987, 703-714.

(3) Mow,C.V., Gibbs,C.M. et al., J. Biomech., 22(8/9), 1989, 853-861.

(4) Armstrong,G.C. and Mow,C.V., J. Bone and Joint Surg., 64, 1982, 88-94.

(5) Töyräs,J., Lyyra-Laitinen,T. et al., J. Biomech., 34, 2001, 251-256.

(6) Uchio,Y., Ochi,M. et al., Med. Eng. Phys., 24, 2002, 431-435.

（7）例えば森浩二 服部耕治ほか, 第 12 回バイオエンジニ アリング学術講演会・秋季セミナ一講演論文集, 2001, 191-192.

(8) Hattori,K., Mori,K. et al., Clinical Biomechanics, $18,2003,553-557$.

（9）竹中慎, 服部耕治ほか, 第 15 回バイオエンジニアリン グ講演会講演論文集, 2003, 303-304.

(10) 例えば Kikuchi,T.,Sakuta,S. et al., Osteoarthiritis and cartilage, 6, 1998, 177-186.

(11) 竹中慎, 大橋徹夫ほか, 第 16 回バイオエンジニアリ ング講演会講演論文集, 2004, 381-382.

(12) 井上裕嗣, 岸本喜久雄ほか, 機論, 61(581), 1995, 153160.

(13) Kuc,R. and Schwartz,M., IEEE Trans., Sonics and Ultrasonics, SU-26(5), 1979, 353-362.

(14) Parker,J.K., Lerner,M.R. et al., Radiology, 153, 1984, 785-788.

(15) Wojcik G., Fornberg B. et al., IEEE Ultrasonic Symp., 1997, 1501-1506.

(16) Bereneger,P.J., J. Computational Physics, 114, 1994, 185-200.

(17) Agemura,D.H., O'brien,D.W. et al, J. Acoust. Soc. Am., 87(4), 1990, 1786-1791

(18) ICRS Cartilage Evaluation Package. Available at: http://www.cartilage.org/files/icrs_evaluation.pdf. Accessed March 4, 2004.

(19) Töyräs,J., Rieppo,J. et al., Phys. Med. Biol., 44, 1999, 2723-2733.

(20) Myers,L.S., Dines,K. et al., J. rheumatology, 22(1), 1994, 109-116.

(21) Töyräs,J., Laasanen,S. et al., Ultrasound in Med. and Biol., 29(3), 2003, 447-454.

(22) Senzig,A.D., Forster,K.F. et al., J. Acoust. Soc. Am., 92(2), 1992, 676-681.

(23) Adler,S.R., Dedrick,K.D. et al., Ultrasound in Med. and Biol., 18(1), 1992, 51-58. 